\title{
Impaired PI3K/Akt Signaling as a Potential Cause of Failure to Precondition Rat Hearts Under Conditions of Simulated Hyperglycemia
}

\author{
M. ZÁLEŠÁK ${ }^{1}$, P. BLAŽÍČEK ${ }^{2}$, I. GABLOVSKÝ ${ }^{1}$, V. LEDVÉNYIOVÁ ${ }^{1}$, M. BARTEKOVÁ ${ }^{1}$, \\ A. ZIEGELHÖFFER ${ }^{1}$, T. RAVINGEROVÁ ${ }^{1}$
}

${ }^{1}$ Institute for Heart Research, Slovak Academy of Sciences and Centre of Excellence of SAS NOREG Bratislava, Slovak Republic, ${ }^{2}$ Laboratory of Clinical Biochemistry and Hematology Alpha Medical, Bratislava, Slovak Republic

Received July 30, 2014

Accepted February 17, 2015

On-line March 24, 2015

\begin{abstract}
Summary
The aim of the study was to evaluate the impact of simulated acute hyperglycemia (HG) on PI3K/Akt signaling in preconditioned and non-preconditioned isolated rat hearts perfused with Krebs-Henseleit solution containing normal $(11 \mathrm{mmol} / \mathrm{l})$ or elevated $(22 \mathrm{mmol} / \mathrm{l})$ glucose subjected to ischemia-reperfusion. Ischemic preconditioning (IP) was induced by two 5-min cycles of coronary occlusion followed by 5-min reperfusion. Protein levels of Akt, phosphorylated (activated) Akt (P-Akt), as well as contents of BAX protein were assayed (Western blotting) in cytosolic fraction of myocardial tissue samples taken prior to and after 30-min global ischemia and 40-min reperfusion. In "normoglycemic" conditions (NG), IP significantly increased P-Akt at the end of long-term ischemia, while reperfusion led to its decrease together with the decline of BAX levels as compared to non-preconditioned hearts. On the contrary, under HG conditions, P-Akt tended to decline in IPhearts after long-term ischemia, and it was significantly higher after reperfusion than in non-preconditioned controls. No significant influence of IP on BAX levels at the end of I/R was observed under HG conditions. It seems that high glucose may influence IP-induced activation of Akt and its downstream targets, as well as maintain persistent Akt activity that may be detrimental for the heart under above conditions.
\end{abstract}

\section{Key words}

Phosphatidylinositol 3-kinase (PI3K) - Protein kinase B (Akt) • Ischemic preconditioning • Simulated hyperglycemia $\bullet$ bcl-2-like protein 4 (BAX)

\section{Corresponding author}

M. Zálešák, Institute for Heart Research, Slovak Academy of Science, P.O. BOX 104, Dúbravská cesta 9, 84005 Bratislava, Slovak Republic. E-mail: mzmzalesak@gmail.com

\section{Introduction}

In 1986 it was first time described by Murry et al. that series of short-time coronary occlusions intercepted with reperfusion, termed as ischemic preconditioning (IP), delays cardiomyocyte death. Preconditioning results in activation of G-protein-coupled receptors by ligands, such as adenosine, alpha adrenergic agonists, delta-opioids and bradykinin (Tyagi and Tayal 2002). It was found that protection afforded by all of the trigger substances could be blocked by protein kinase $\mathrm{C}$ (PKC) inhibitors, which indicates that PKC could be a common target of these ligands (Downey et al. 2007). The mechanism of PKC activation may involve stimulation of phospholipase C via GPCR (G proteinscoupled receptors) that subsequently cleaves phosphatidylinositol-3 phosphate (PIP3) to inositol-1, 4, 5-triphosphate and diacylglycerol, which binds to $\mathrm{PKC}$ and activates it (Simkhovich et al. 2013). Isolated rat heart experiments revealed that activation of PKC leads to its translocation to particular fraction associated with improvement of cardiac function (Kawamura et al. 1998). A basic property of PKC is considered to be modulation of mitochondrial $\mathrm{K}_{\text {ATP }}^{+}$channels (Wang et al. 2001). 
Their opening causes a mitochondrial swelling. Expansion of the mitochondrial matrix volume improves fatty acid oxidation, respiration and energy production. Thus, this mechanism has become considered as one of key hypotheses to explain protection by IP (O'Rourke 2004). Experiments with isolated rat hearts have shown that phosphatidylinositol-3 kinase (PI3K)/protein kinase $\mathrm{B}$ (Akt) stimulation occurs upstream of PKC activation (Tong et al. 2000). Akt kinase is stimulated by a number of receptor tyrosine kinases and this is mediated by the action of PI3K (Hemmings and Restuccia 2012). It was proposed that PI3K may be also downstream of PKC (Walser et al. 2013). PI3K/Akt promotes physiological heart growth and inhibits pathological myocardial hypertrophy (Walsh 2006). Akt also phosphorylates Bcl2-associated death promoter, decreases caspase-3 activity (Hussain et al. 2014), upregulates antiapoptotic B-cell lymphoma protein (Bcl-2) (Pugazhenthi et al. 2000) and prevents conformational changes of bcl-2-like protein 4 (BAX), as well as its incorporation into a mitochondrial membrane. Importantly, Rajtík et al. (2012) demonstrated that ischemia-reperfusion (I/R) injury leads to a decrease of $\mathrm{Bcl}-2 / \mathrm{BAX}$ ratio associated with myocardial dysfunction and apoptosis. On the other hand, increased Bcl-2/BAX indicates activation of antiapoptotic (or suppression of apoptotic) processes leading to antiinfarct protection (Hausenloy and Yellon 2004). This effect of PI3K/Akt pathway was confirmed in the experiments with Langendorff-perfused rat hearts and in in vivo settings of adaptation to intermittent hypobaric hypoxia (Ravingerová et al. 2007).

Many clinical studies demonstrated that unstable angina pectoris (UAP) decreases mortality in patients with acute myocardial infarction (AMI), the most severe form of ischemic heart disease (Kloner et al. 1995, 1998, Nakagawa et al. 1995) and, therefore, is considered as a clinical analogue of IP (Švorc et al. 2003). In contrast, other authors observed higher mortality in UAP patients than in non-UAP patients after AMI (Behar et al. 1992). Distinct effects of UAP can be attributed to different personal history (e.g., presence of comorbidities, such as diabetes mellitus, systemic arterial hypertension, hyperlipidemia) and aging. Ischemic heart disease is often combined with these risk factors (Ferdinandy et al. 2007). Risk factors may play a dual role in pathogenesis of I/R and besides deleterious effects, some factors may trigger adaptive processes in the heart resulting in its greater ischemic tolerance (Ravingerová et al. 2012). However, other experimental studies in open-chest animals have demonstrated that in pathologically altered hearts (e.g., in acute hyperglycemia), protective IP-effect was blunted (Vladic et al. 2011, Kersten et al. 1998). Tsang et al. (2005) have reported that under conditions of experimental diabetes mellitus II type, the heart requires more IP stimuli to reach PI3K/Akt activation. Moreover, under conditions of hypercholesterolemia, IP even more impaired heart resistance to ischemia (Juhasz et al. 2004). In our previous study (Zálešák et al. 2014), we have also observed negative effect of IP under conditions of simulated hyperglycemia, where preconditioned rat hearts had larger size of infarction than non-preconditioned controls. The aims of our present study were to disclose some molecular mechanisms that might underlie this negative effect of IP under conditions of hyperglycemia, with particular regards to the changes in PI3K/Akt signaling.

\section{Material and Methods}

\section{Animals and experimental protocols}

Adult male Wistar rats (250-300 g body weight) fed a standard diet and tap water ad libitum were used in the experiments. Animals were anesthetized by sodium pentobarbitone in a dose of $50-60 \mathrm{mg} / \mathrm{kg}$ (i. p.) combined with heparin. All studies were performed in accordance with the Guide for the Care and Use of Laboratory Animals published by US National Institutes of Health (NIH publication No 85-23, revised 1996) and approved by the Animal Health and Animal Welfare Division of the State Veterinary and Food Administration of the Slovak Republic. Rats were randomly divided into four groups, and further experiments were performed in Langendorff-perfused hearts.

\section{Perfusion technique}

After rapid excision, the hearts were placed in ice-cold perfusion buffer, cannulated via the aorta and then perfused in the Langendorff mode with KrebsHenseleit $(\mathrm{KH})$ solution gassed with $95 \% \mathrm{O}_{2}$ and $5 \%$ $\mathrm{CO}_{2}$ (pH 7.4) at constant perfusion pressure of $73 \mathrm{~mm} \mathrm{Hg}$ and $37^{\circ} \mathrm{C}$. $\mathrm{KH}$ solution contained (in mmol/l): $\mathrm{NaCl}$ 118.0; $\mathrm{KCl}$ 3.2; $\mathrm{MgSO}_{4}$ 1.2; $\mathrm{NaHCO}_{3}$ 25.0; $\mathrm{KH}_{2} \mathrm{PO}_{4}$ 1.18; $\mathrm{CaCl}_{2}$ 2.5; glucose 11.1 or 22.2. Left ventricular (LV) pressure was measured by a water-filled balloon (inflated to obtain end-diastolic pressure of 5-7 $\mathrm{mm} \mathrm{Hg}$ ) inserted into $\mathrm{LV}$ and connected to a pressure transducer (MLP physiological pressure transducer, ADInstruments, Germany). LV systolic and diastolic pressure, LV 
developed pressure (LVDP; systolic minus diastolic pressure), maximal rates of pressure development and fall, $+\mathrm{dP} / \mathrm{dt}_{\max }$ and $-\mathrm{dP} / \mathrm{dt}_{\max }$, as indexes of contraction and relaxation, heart rate (HR, derived from electrogram) and coronary flow were used to assess heart function using Power-Lab/8SP Chart 7 software (ADInstruments, Germany). The hearts were allowed to stabilize (20$40 \mathrm{~min}$ ) before further interventions (Fig. 1).

\section{Protocols of ischemia/reperfusion}

1. In the control normoglycemic (C/NG) and hyperglycemic $(\mathrm{C} / \mathrm{HG})$ groups, after stabilization (20 min) and additional 20-min perfusion to match the protocol of IP, the hearts were exposed to 30-min global zero-flow ischemia followed by $40-\mathrm{min}$ recovery of perfusion $-\mathrm{I} / \mathrm{R}$ injury. During the whole protocol, the hearts were perfused either with a standard $\mathrm{KH}$ solution (concentration of glucose $11 \mathrm{mmol} / \mathrm{l}$ ) or with $\mathrm{KH}$ solution containing $22 \mathrm{mmol} / \mathrm{l}$ glucose in the case of simulated hyperglycemia. Number of animals per group was 4 .

2. In the preconditioned normoglycemic (IP/NG) and hyperglycemic (IP/HG) group, after stabilization (20 $\mathrm{min}$ ), the hearts were subjected to two cycles of ischemic preconditioning (IP) induced by 5-min stop of aortic inflow and 5-min recovery of perfusion, prior to sustained I/R as in 1 . Numbers of animals per group was 4 . The schemes of both protocols are shown in Figure 1.

\section{Preparation of tissue protein fractions}

Sampling of tissue for Western blot analysis was performed as described previously (Barlaka et al. 2013, Ravingerová et al. 2009, 2013). In non-preconditioned and preconditioned hearts, small amounts of left ventricular myocardial tissue (equal size) were taken prior to ischemia, after 30-min global ischemia and after 40-min reperfusion and stored in liquid nitrogen until usage. Timing of sampling is shown in Figure 1. The samples were resuspended in ice-cold buffer containing (in $\mathrm{mmol} / \mathrm{l}$ ): Tris- $\mathrm{HCl} 20$, sucrose 250, ethylene-glycolbis(2-aminoethylether)-N,N,N,N-tetraacetic acid 1.0, dithiotreitol 1.0, phenylmethylsulphonylfluoride 1.0 and sodium orthovanadate 0.5 ( $\mathrm{pH} 7.4)$ and homogenized with a Teflon homogenizer. The homogenates were centrifuged at $3000 \mathrm{xg}$ for $5 \mathrm{~min}$ at $4{ }^{\circ} \mathrm{C}$, pellets after centrifugation were discarded and the supernatants were centrifuged again at $10000 \mathrm{xg}$ for $30 \mathrm{~min}$. The supernatants after the second centrifugation, termed as cytosolic fraction were used for further analysis. Protein concentration was estimated by the method of Bradford (1976).

\section{Electrophoresis and Western blot analysis}

Samples of protein fraction containing equal amounts of protein per lane $(40 \mu \mathrm{g}$ per lane) were separated by sodium dodecyl sulfate-polyacrylamide gel electrophoresis (SDS-PAGE). For Western blot analysis, separated proteins were transferred from gel to a nitrocellulose membrane. The quality of the transfer was controlled by Ponceau $\mathrm{S}$ staining of nitrocellulose membranes after the transfer and protein loading by using glyceraldehyde-3-phosphate dehydrogenase (GAPDH) as a housekeeper. Specific anti-Akt kinase, anti-Bcl-2 and anti-BAX (from Santa Cruz Biotechnology) and antiphospho (P)-Akt kinase (from Cell Signaling Technology) antibodies were used for the primary immunodetection. Peroxidase-labelled anti-rabbit immunoglobulin (Cell Signaling Technology) was used as the secondary antibody. Bound antibodies were detected by the enhanced chemiluminiscence detection method using Carestream PC program. Protein levels of Akt, P-Akt and BAX were normalized to GAPDH. PI3K/Akt activity was expressed as a ratio of P-Akt and Akt. ColorBurst marker (Sigma Aldrich) was used for quantitative molecular mass determination of transferred proteins.

\section{Statistical evaluation}

All data are expressed as means \pm SEM. Comparison of individual groups was performed by multifactorial analysis of variances (ANOVA) and subsequently by Student's $t$-test. Differences between the groups were considered significant at $\mathrm{p}<0.05$.

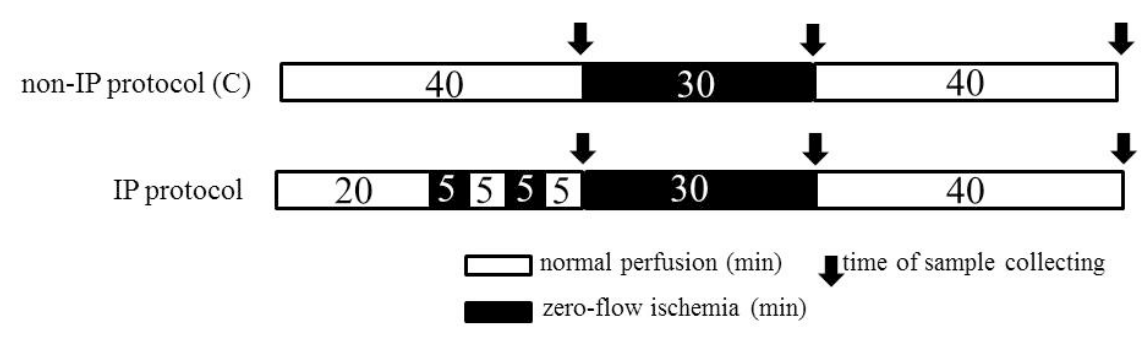

Fig. 1. Experimental protocol of zeroflow ischemia and ischemic preconditioning. IP - ischemic preconditioning, C - non-IP control protocol 
Table 1. Preischemic values of parameters of myocardial function in controls and ischemically preconditioned rat hearts under conditions of normoglycemia (NG) and hyperglycemia (HG).

\begin{tabular}{lcccc}
\hline Group & C/NG & IP/NG & C/HG & IP/HG \\
\hline$H R($ beats/min $)$ & $246 \pm 10.9$ & $248 \pm 12.1$ & $207 \pm 10.5$ & $239 \pm 5.2$ \\
$C F(\mathrm{ml} / \mathrm{min})$ & $9.1 \pm 1.4$ & $12 \pm 0.9$ & $8.8 \pm 0.5$ & $10.3 \pm 0.4$ \\
$L V D P(\mathrm{~mm} \mathrm{Hg})$ & $67.8 \pm 15.0$ & $73.8 \pm 11.4$ & $84.2 \pm 8.1$ & $76.7 \pm 8.8$ \\
$+(d P / d t)_{\max }(\mathrm{mm} \mathrm{Hg} / \mathrm{s})$ & $1793 \pm 337$ & $1927 \pm 345$ & $2013 \pm 258$ & $2046 \pm 228$ \\
$-(d P / d t)_{\max }(\mathrm{mm} \mathrm{Hg} / \mathrm{s})$ & $1119 \pm 274$ & $1149 \pm 233$ & $1327 \pm 150$ & $1242 \pm 125$ \\
\hline
\end{tabular}

$\mathrm{C}$ - controls, IP - ischemic preconditioning. HR - heart rate, CF - coronary flow, LVDP - left ventricular developed pressure, $+(\mathrm{dp} / \mathrm{dt})_{\max }$ - maximal rate of pressure development, $-(\mathrm{dP} / \mathrm{dt})_{\max }$ - maximal rate of pressure fall. Data are expressed as means $\pm S E M, n=4$ hearts per group.

\section{Results}

\section{Characteristics of isolated hearts}

The value of heart rate, LVDP, $+\mathrm{dP} / \mathrm{dt}_{\max }$, $-\mathrm{dP} / \mathrm{dt}_{\max }$, and coronary flow in the NG and $\mathrm{HG}$ control groups, as well as in the preconditioned $\mathrm{NG}$ and $\mathrm{HG}$ groups are summarized in Table 1. There were no significant differences in the values of these parameters between the groups prior to sustained ischemia.
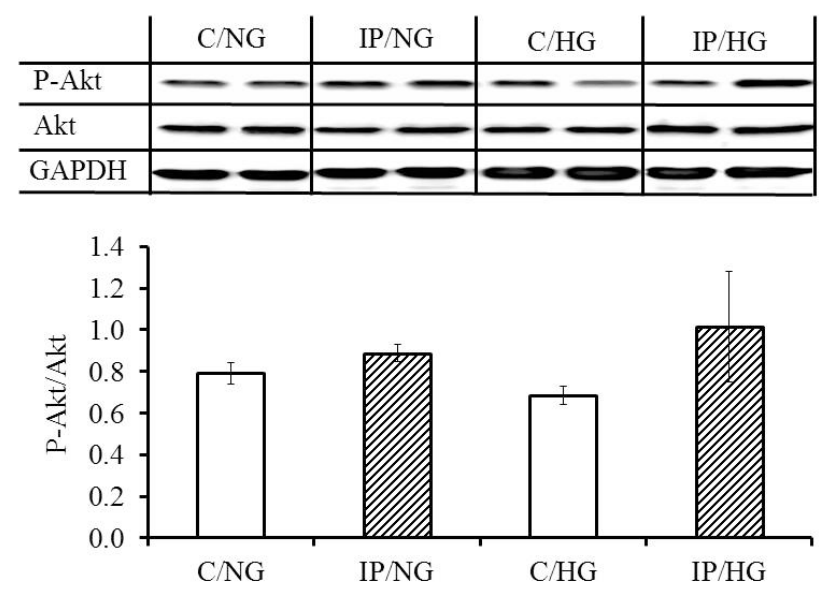

Fig. 2. Cytosolic protein levels of Akt, P-Akt, GAPDH directly after stabilization period or IP. Effect of normoglycemia and simulated hyperglycemia. Upper panel: Representative blots of P-Akt, Akt and GAPDH as a loading control. Bottom panel: Quantification of blots by scanning densitometry. Results are shown as a ratio of P-Akt and Akt (normalized to GAPDH) and expressed as means $\pm \mathrm{SEM}, \mathrm{n}=4$ hearts per group. IP - ischemic preconditioning, $\mathrm{C}-$ non-IP controls, NG - normal glucose, HG - simulated hyperglycemia

Akt phosphorylation prior to and after long-term ischemia and after reperfusion

Under conditions of NG, preconditioning tended to increase myocardial P-Akt contents, although the difference between non-preconditioned and preconditioned groups did not reach the level of significance (Fig. 2). Neither did IP under HG conditions influenced Akt phosphorylation (Fig. 2). No differences in the levels of P-Akt between the control NG and HG groups were observed (Fig. 2).

\begin{tabular}{l|c|c|c|c|} 
& $\mathrm{C} / \mathrm{NG}$ & $\mathrm{IP} / \mathrm{NG}$ & $\mathrm{C} / \mathrm{HG}$ & $\mathrm{IP} / \mathrm{HG}$ \\
\hline $\mathrm{P}-\mathrm{Akt}$ & - & - & - & - \\
\hline $\mathrm{Akt}$ & $-\cdots$ & - & - & - \\
\hline $\mathrm{GAPDH}$ & - & & - & - \\
\hline
\end{tabular}

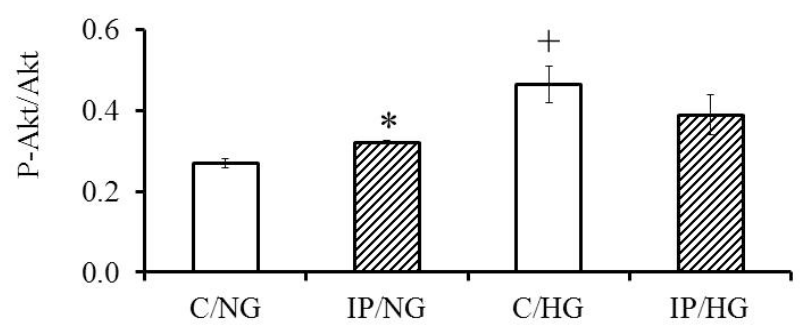

Fig. 3. Cytosolic protein levels of Akt, P-Akt, GAPDH, after longterm zero-flow ischemia. Effect of normoglycemia and simulated hyperglycemia. Upper panel: Representative blots of P-Akt, Akt and GAPDH as a loading control. Bottom panel: Quantification of blots by scanning densitometry. Results are shown as a ratio of P-Akt and Akt (normalized to GAPDH) and expressed as means \pm SEM, $n=4$ hearts per group. ${ }^{*} p<0.05$, IP/NG vs. C/NG, ${ }^{+} p<0.05$, $\mathrm{C} / \mathrm{NG}$ vs. C/HG; IP - ischemic preconditioning, $\mathrm{C}-$ non-IP controls, $\mathrm{NG}$ - normal glucose, $\mathrm{HG}$ - simulated hyperglycemia

On the other hand, in the IP group, P-Akt was significantly increased at the end of index ischemia as compared with the non-preconditioned controls under NG conditions $(0.32 \pm 0.004$ vs. $0.27 \pm 0.01, \mathrm{p}<0.05)$ (Fig. 3$)$. However, under HG conditions, no significant changes in P-Akt/Akt between the groups of preconditioned hearts and non-preconditioned controls were observed, moreover, P-Akt/Akt in IP group tended to be reduced but the difference between the IP and $\mathrm{C}$ groups was not significant (Fig. 3). In contrast, in non-IP controls, HG 
significantly increased P-Akt/Akt as compared with NG controls $(0.46 \pm 0.04$ vs. $0.27 \pm 0.01, \mathrm{p}<0.05)$ (Fig. 3 ).

After reperfusion, P-Akt/Akt in the IP group was significantly lower than in the $\mathrm{C}$ group under $\mathrm{NG}$ conditions $(1.57 \pm 0.07$ vs. $2.92 \pm 0.1, \mathrm{p}<0.05)$ (Fig. 4), whereas under $\mathrm{HG}$ conditions, it was higher than in the $\mathrm{C}$ group $(1.82 \pm 0.17$ vs. $1.15 \pm 0.12, \mathrm{p}<0.05)$. In non-IP controls, HG significantly decreased P-Akt/Akt as compared to its value in the NG control group $(1.15 \pm 0.11$ vs. $2.92 \pm 0.1, \mathrm{p}<0.5$ ) (Fig. 4).

Influence of preconditioning on the levels of Bcl-2 and $B A X$ proteins at the end of $I / R$ protocol

Under NG conditions, IP decreased BAX protein value against controls $(0.302 \pm 0.01$ vs. $0.37 \pm 0.01, \mathrm{p}<0.05)$ (Fig. 5A). However, under HG conditions, no significant decline of BAX was observed in the preconditioned group ( $0.39 \pm 0.02$ vs. $0.43 \pm 0.03, \mathrm{p}=0.2)$ (Fig. $5 \mathrm{~B}$ ). Under both conditions the levels of $\mathrm{Bcl}-2$ were not changed (data not shown).
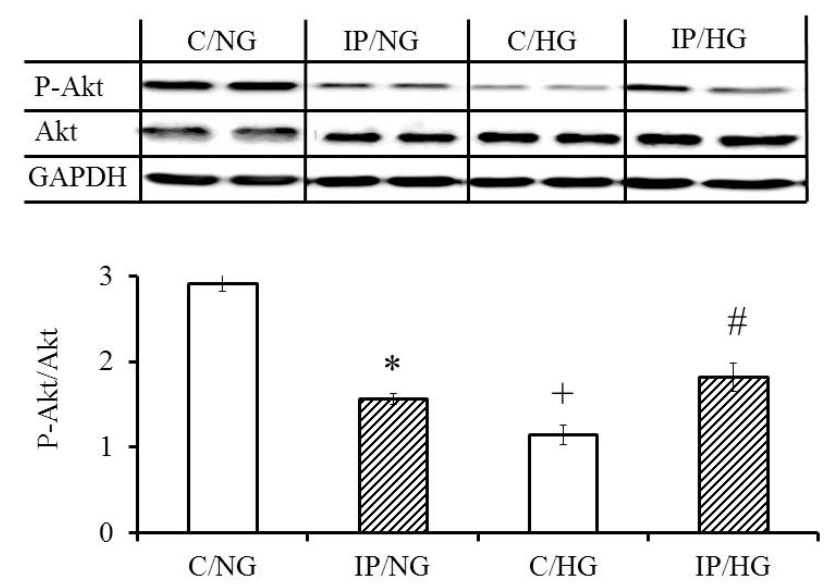

Fig. 4. Cytosolic protein levels of Akt, P-Akt, GAPDH after longterm reperfusion. Effect of normoglycemia and simulated hyperglycemia. Upper panel: Representative blots of P-Akt, Akt and GAPDH as a loading control. Bottom panel: Quantification of blots by scanning densitometry. Results are shown as a ratio of P-Akt and Akt (normalized to GAPDH) and expressed as means \pm SEM, $n=4$ hearts per group. * $p<0.05$, IP/NG vs. C/NG, \# $p<0.05, I P / H G$ vs. C/HG, ${ }^{+} p<0.05, C / N G$ vs. C/HG; IP ischemic preconditioning, $C$ - non-IP controls, NG - normal glucose, HG - simulated hyperglycemia
A.

\begin{tabular}{l|c|c|} 
& $\mathrm{C} / \mathrm{NG}$ & $\mathrm{IP} / \mathrm{NG}$ \\
\hline $\mathrm{BAX}$ & - & - \\
\hline $\mathrm{GAPDH}$ & - & - \\
\hline
\end{tabular}

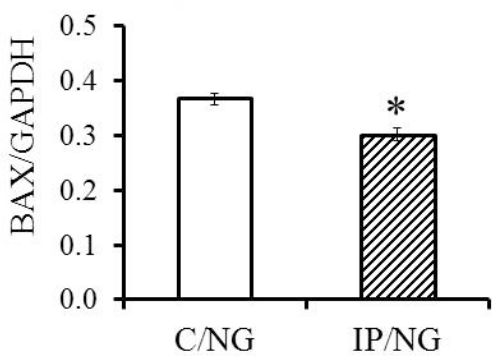

B.
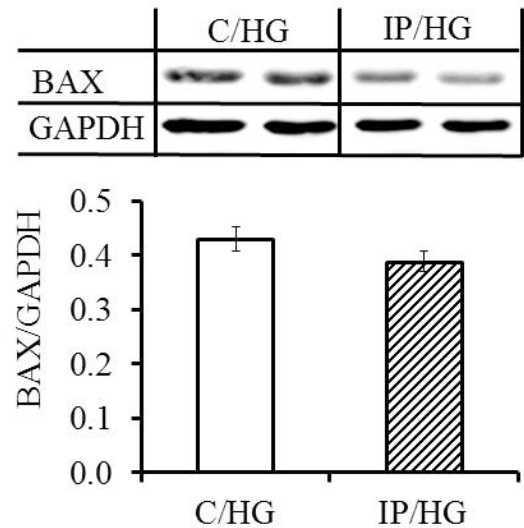

Fig. 5. Cytosolic protein levels of $B A X$ and GAPDH at the end of long-term I/R under normoglycemia (A) and under simulated hyperglycemia (B). Upper panel: Representative blots of BAX and GAPDH as a loading control. Bottom panel: Quantification of blots by scanning densitometry. Results are shown as a ratio of BAX and GAPDH. Results are expressed as means \pm SEM, $n=4$ hearts per group. $* \mathrm{p}<0.05$, ischemic preconditioning (IP) group vs. respective non-IP control group (C); NG - normal glucose, $\mathrm{HG}$ - simulated hyperglycemia

\section{Discussion}

Our study showed that following two cycles of ischemic preconditioning, PI3K/Akt signaling may start to become up-regulated (Fig. 2), but more apparently, Akt activation occurs during the period of long-term zeroflow ischemia in isolated rat hearts under NG conditions (Fig. 3) that subsequently may lead to a decrease in the level of proapoptotic BAX protein after I/R (Fig. 5A). As no changes in the levels of Bcl-2 were observed, antiapoptotic effect was not presented as the ratio of Bcl-2 and BAX since it would not bring any important additional information. It seems that Akt activation by IP becomes more evident after longer period of time, e.g., like after providing of three IP-cycles when the P-Akt was elevated significantly (Yang et al. 2013). Thus, we confirmed that activation of Akt plays one of the crucial roles in the mechanisms of IP (Hausenloy and Yellon 2006). Antiapoptotic effect of downregulated BAX in the rat hearts caused by IP (documented by decreased DNA fragmentation) has been also demonstrated in the study of Piot et al. (1997). However, at the end of long-term reperfusion in the preconditioned hearts, lower Akt activity than in the control group perfused with normal glucose medium was observed in our experiments (Fig. 4). This finding is in accordance with the study of $\mathrm{Zu}$ et al. (2011) who showed depressed levels of P-Akt and elevated lipid phosphatase and tensin homologue 
deleted on chromosome ten (PTEN) in sarcoplasm of the preconditioned hearts compared with non-preconditioned controls at the end of $\mathrm{I} / \mathrm{R}$. These findings were associated with attenuated PTEN and BAX localization in mitochondria, reactive oxygen species production and depressed infarct size in the IP group. PTEN dephosphorylates the lipid second messenger (PIP3) that prevents activation of the Akt kinase (Newton and Trotman 2014). Therefore, PTEN could be considered one of the negative regulators of PI3K/Akt signaling, as well as protein phosphatases 1 and 2A (Fan et al. 2010), pleckstrin homology domain leucine-rich repeat protein phosphatase-1 (Liao and Hung 2010, Miyamoto et al. 2010), and also protein kinase D1, likewise in intestinal epithelial cells (Ni et al. 2014). PTEN probably plays a pivotal role in the effectivity of cardioprotection provided by IP. It is supported by the failure of IP in PTEN-knockouted mice leading to an enhanced size of infarction as compared with that in the non-IP controls (Zheng et al. 2014).

Elevated glucose in medium reversed IP-induced modulations of sarcoplasmic P-Akt levels. After longterm zero-flow ischemia, P-Akt in preconditioned hearts did not differ from that in the non-IP controls (Fig. 3), and at the end of $I / R$ it was significantly higher than in respective controls (Fig. 4). These changes in Akt phosphorylation were associated with attenuation of IP-mediated lowering of BAX value (Fig. 5B). In our previous study, HG also reversed IP-induced effect on heart resistance to $I / R$ injury (Zálešák et al. 2014). In that study, decreased resistance of preconditioned hearts to $\mathrm{I} / \mathrm{R}$ was manifested by significantly elevated infarct size (normalized to the size of area at risk, AR) against that in the non-IP control group (IS/AR: $21.4 \pm 2.2 \%$ vs. $14.3 \pm 1.3 \%$ ), while under NG conditions, antiinfarct IP-induced protection was confirmed (IS/AR: $8.8 \pm 1 \%$ vs. $17.1 \pm 1.2 \%$ ). It is in agreement with numerous studies that documented negative impact of lifestyle-related comorbidities, such as diabetes, on the mechanisms of innate cardioprotection (Ferdinandy et al. 2014, 2007, Ravingerová et al. 2012). Similar switching of IP-induced effect on heart resistance against development of infarction was achieved by insulin applied during the entire perfusion protocol of $\mathrm{I} / \mathrm{R}$ via Akt-dependent mechanisms (Fullmer et al. 2013). Persistent cardiac specific Akt activation in transgenic mice also depressed cardiac resistance against infarction (Nagoshi et al. 2005). Moreover, Akt hyperactivation suppressed expression of antioxidant proteins due to inhibition of forkhead family transcription factors, which normally upregulate antioxidant proteins (Los et al. 2009, Nogueira et al. 2008). Alterations in PI3K/Akt signaling due to Akt hyperactivation may be a cause of these detrimental effects of IP on the heart.

Similar modulation of P-Akt as by IP under NG conditions (P-Akt/Akt elevation after zero-flow ischemia and its depression after reperfusion), was achieved in the non-IP controls with elevated glucose in medium (Figs 3, 4). PI3K/Akt modulation by elevated glucose was previously observed in the cell culture experiments (Yeshao et al. 2005). Moreover, high glucose or hyperosmosis provided by perfusion with mannitol in isolated rat hearts elevated the levels of cardioprotective heat shock protein 90 (Chen et al. 2006). In addition, lower total amount of heart fatty acid binding protein (h-FABP, a marker of cell injury) released from the impaired non-IP hearts under HG than under NG conditions suggests that high glucose medium may exert rather protective effects against severe $I / R$ injury under certain conditions (Zálešák et al. 2014). Experiments with isolated rat hearts also showed enhanced resistance of hearts with acute streptozotocin-induced diabetes to myocardial $\mathrm{I} / \mathrm{R}$ by demonstrating lower release of creatine phosphokinase during I/R (Chen et al. 2006).

Experimental results confirm that PI3K/Akt signaling pathway plays a pivotal role in the cardioprotection. However, is seems that long-termI/R-related regulation of PI3K/Akt signaling proved by elevated P-Akt in sarcoplasm at early stage after IP and by its decrease at the end of experiment is essential for effective execution of cardioprotection.

\section{Study limitations}

In this study, normoglycemic and hyperglycemic solutions had different osmotic concentration that might affect the results. It is very probable that influence of high concentration of glucose on intracellular signaling mechanism may involve relative hyperosmosis. Influence of induced hyperosmosis on cardioprotection mediated by IP would be the subject of our further research to differentiate metabolic and non-metabolic effects.

\section{Conclusions}

Simulated acute hyperglycemia alters long-termI/R-related PI3K/Akt signaling triggered by ischemic preconditioning. A lack of PI3K/Akt up-regulation at early stage of $I / R$ protocol and negative PI3K/Akt 
regulation at the end of reperfusion, under high glucose conditions, probably plays a role in the failure of preconditioning to confer cardioprotection. PI3K/Akt regulation by high glucose in non-preconditioned hearts similar to that in the preconditioned ones under normal glucose conditions may serve as one of potential explanations of their better resistance against severe $\mathrm{I} / \mathrm{R}$ injury under certain conditions.

\section{Conflict of Interest}

There is no conflict of interest.

\section{Acknowledgements}

The authors express their gratitude to Ing. D. Pancza and Mrs. I. Formánková for their excellent technical assistance. This study was supported by grants VEGA SR 1/0638/12, VEGA SR 2/0201/15, APVV-0102-11.

\section{List of Abbreviations}

Akt Protein kinase B

\begin{tabular}{|c|c|}
\hline AMI & Acute myocardial infarction \\
\hline BAX & Bcl-2 like protein \\
\hline Bcl-2 & B-cell lymphoma protein \\
\hline $\mathrm{CF}$ & Coronary flow \\
\hline$+\mathrm{dp} / \mathrm{dt}_{\max }$ & Maximal rate of pressure development \\
\hline$-\mathrm{dp} / \mathrm{dt}_{\max }$ & Maximal rate of pressure fall \\
\hline GAPDH & Glyceraldehyde-3-phosphate dehydrogenase \\
\hline h-FABP & Heart fatty acid binding protein \\
\hline $\mathrm{HG}$ & High glucose, simulated hyperglycemia \\
\hline HR & Heart rate \\
\hline IP & Ischemic preconditioning \\
\hline $\mathrm{I} / \mathrm{R}$ & Ischemia/reperfusion \\
\hline LV & Left ventricle \\
\hline LVDP & Left ventricular developed pressure \\
\hline NG & Normal glucose, normoglycemia \\
\hline P-Akt & Phosphorylated protein kinase B \\
\hline PI3K & Phosphatidylinositol-3 kinase \\
\hline PIP3 & Phosphatidylinositol-3 phosphate \\
\hline PKC & Protein kinase $\mathrm{C}$ \\
\hline UAP & Unstable angina pectoris \\
\hline
\end{tabular}

\section{References}

BARLAKA E, LEDVÉNYIOVÁ V, GALATOU E, FERKO M, ČARNICKÁ S, RAVINGEROVÁ T, LAZOU A: Delayed cardioprotective effects of WY-14643 are associated with inhibition of MMP-2 and modulation of Bcl-2 family proteins through PPAR- $\alpha$ activation in rat hearts subjected to global ischaemia-reperfusion. Can $J$ Physiol Pharmacol 91: 608-616, 2013.

BEHAR S, REICHER-REISS H, ABINADER E, AGMON J, FRIEDMAN Y, BARZILAI J, KAPLINSKY E, KAULI N, KISHON Y, PALANT A ET AL.: The prognostic significance of angina pectoris precede the occurrence of a first acute infarction in 4166 consecutive hospitalized patients. Am Heart J 123: 1481-1486, 1992.

BRADFORD MM: A rapid and sensitive method for the quantification of microgram quantities of protein utilizing the principle of protein-dye binding. Anal Biochem 72: 248-254, 1976.

CHEN H, SHEN WL, WANG XH, CHEN HZ, GU JZ, FU J, NI YF, GAO PJ, ZHU DL, HIGASHINO H: Paradoxically enhanced heart tolerance to ischemia in type 1 diabetes and role of increased osmolarity. Clin Exp Pharmacol Physiol 33: 910-916, 2006.

DOWNEY JM, DAVIS AM, COHEN MV: Signaling pathways in ischemic preconditioning. Heart Fail Rev 12: 181$188,2007$.

FAN WJ, VAN VUUREN D, GENADE S, LOCHNER A: Kinases and phosphatases in ischaemic preconditioning: a reevaluation. Basic Res Cardiol 105: 495-511, 2010.

FERDINANDY P, SCHULZ R, BAXTER GF: Interaction of cardiovascular risk factors with myocardial ischemia/reperfusion injury, preconditioning, and postconditioning. Pharmacol Rev 59: 418-458, 2007.

FERDINANDY P, HAUSENLOY DJ, HEUSCH G, BAXTER GF, SCHULZ R: Interaction of risk factors, comorbidities, and comedications with ischemia/reperfusion injury and cardioprotection by preconditioning, postconditioning, and remote conditioning: Pharmacol Rev 66: 1142-1174, 2014.

FULLMER TM, PEI S, ZHU Y, SLOAN C, MANZANARES R, HENRIE B, PIRES KM, COX JE, ABEL ED, BOUDINA S: Insulin suppresses ischemic preconditioning-mediated cardioprotection through Akt-dependent mechanisms. J Mol Cell Cardiol 64: 20-29, 2013.

HAUSENLOY DJ, YELLON DM: New directions for protecting the heart against ischaemia-reperfusion injury: targeting the Reperfusion Injury Salvage Kinase (RISK)-pathway. Cardiovasc Res 61: 448-460, 2004. 
HAUSENLOY DJ, YELLON DM: Survival kinases in ischemic preconditioning and postconditioning. Cardiovasc Res 70: 240-253, 2006.

HEMMINGS BA, RESTUCCIA DF: PI3K-PKB/Akt pathway. Cold Spring Harb Respect Biol 4: a011189, 2012.

HUSSAIN A, GHARANEI AM, NAGRA AS, MADDOCK HL: Caspase inhibition via A3 adenosine receptors: a new cardioprotective mechanism against myocardial infarction. Cardiovasc Drugs Ther 28: 19-32, 2014.

JUHASZ B, DER P, TUROCZI T, BACSKAY I, VARGA E, TOSAKI A: Preconditioning in intact and previously diseased myocardium: laboratory or clinical dilemma? Antioxid Redox Signal 6: 325-333, 2004.

KAWAMURA S, YOSHIDA KI, MIURA T, MIZUKAMI Y, MATSUZAKI M: Ischemic preconditioning translocates $\mathrm{PKC}-\delta$ and $-\varepsilon$, which mediate functional protection in isolated rat heart. Am J Physiol 275: H2266-H2271, 1998.

KERSTEN JR, SCHMELING TJ, ORTH KG, PAGEL PS, WARLTIER DC: Acute hyperglycemia abolishes ischemic preconditioning in vivo. Am J Physiol 275: H721-H725, 1998.

KLONER RA, SHOOK T, PRZYKLENK K, DAVIS VG, JUNIO L, MATTHEWS RV, BURSTEIN S, GIBSON CM, POOLE WK, CANNON CP, MCCABE CH, BRAUNWALD E: Previous angina alters in-hospital outcome in TIMI 4. A clinical correlate to preconditioning? Circulation 91: 37-45, 1995.

KLONER RA, SHOOK T, ANTMAN EM, CANNON CP, PRZYKLENK K, YOO K, MCCABE CH, BRAUNWALD E: Prospective temporal analysis of the onset of preinfarction angina versus outcome: an ancillary study in TIMI-9B. Circulation 97: 1042-1045, 1998.

LIAO Y, HUNG MC: Physiological regulation of Akt activity and stability. Am J Transl Res 2: 19-42, 2010.

LOS M, MADDIKA S, ERB B, SCHULZE-OSTHOFF K: Switching Akt: from survival signaling to deadly response. Bioessays 31: 492-495, 2009.

MIYAMOTO S, PURCELL NH, SMITH JM, GAO T, WHITTAKER R, HUANG K, CASTILLO R, GLEMBOTSKI CC, SUSSMAN MA, NEWTON AC, BROWN JH: PHLPP-1 negatively regulates Akt activity and survival in the heart. Circ Res 107: 476-484, 2010.

MURRY CE, JENNINGS RB, REIMER KA: Preconditioning with ischemia: a delay of lethal cell injury in ischemic myocardium. Circulation 74: 1124-1136, 1986.

NAGOSHI T, MATSUI T, AOYAMA T, LERI A, ANVERSA P, LI L, OGAWA W, DEL MONTE F, GWATHMEY JK, GRAZETTE L, HEMMINGS B, KASS DA, CHAMPION HC, ROSENZWEIG A: PI3K rescues the detrimental effects of chronic Akt activation in the heart during ischemia/reperfusion injury. J Clin Invest 115 : 2128-2138, 2005.

NEWTON AC, TROTMAN LC: Turning off AKT: PHLPP as a drug target. Annu Rev Pharmacol Toxicol 54: 537-558, 2014.

NI Y, SINNETT-SMITH J, YOUNG SH, ROZENGURT E: PKD1 mediates negative feedback of PI3K/Akt activation in response to G protein-coupled receptors. PLoS One 8: e73149, 2013.

NOGUEIRA V, PARK Y, CHEN CC, XU PZ, CHEN ML, TONIC I, UNTERMAN T, HAY N: Akt determines replicative senescence and oxidative or oncogenic premature senescence and sensitizes cell to oxidative apoptosis. Cancer Cell 14: 458-470, 2008.

O'ROURKE B: Evidence for mitochondrial $\mathrm{K}^{+}$channels and their role in cardioprotection. Circ Res 94: 420-432, 2004.

PIOT CA, PADMANABAN D, URSELL PC, SIEVERS RE, WOLFE CL: Ischemic preconditioning decreases apoptosis in rat hearts in vivo. Circulation 96: 1598-1604, 1997.

PUGAZHENTHI S, NESTEROVA A, SABLE C, HEIDENREICH KA, BOXER LM, HEASLEY LE, REUSCH JE: Akt/protein kinase B up-regulates Bcl-2 expression through cAMP-response element-binding protein. $J$ Biol Chem 275: 10761-10766, 2000.

RAJTÍK T, ČARNICKÁ S, SZOBI A, MESÁROŠOVÁ L, MÁŤUŠ M, ŠVEC P, RAVINGEROVÁ T, ADAMEOVÁ A: Pleiotropic effects of simvastatin are associated with mitigation of apoptotic component of cell death upon lethal myocardial reperfusion-induced injury. Physiol Res 61 (Suppl 2): S33-S41, 2012.

RAVINGEROVÁ T, MATEJÍKOVÁ J, NECKÁŘ J, ANDELOVÁ E, KOLÁŘ F: Differential role of PI3K/Akt pathway in the infarct size limitation and antiarrhytmic protection in the rat heart. Mol Cell Biochem 297: 111120, 2007. 
RAVINGEROVÁ T, ADAMEOVÁ A, KELLY T, ANTONOPOULOU E, PANCZA D, ONDREJČÁKOVÁ M, KHANDELWAL VK, ČARNICKÁ S, LAZOU A: Changes in PPAR gene expression and myocardial tolerance to ischaemia: relevance to pleiotropic effects of statins. Can J Physiol Pharmacol 87: 1028-1036, 2009.

RAVINGEROVÁ T, ČARNICKÁ S, NEMČEKOVÁ M, LEDVÉNYIOVÁ V, ADAMEOVÁ A, KHANDELWAL VK, ZÁLEŠÁK M, KOLÁŘ F: The impact of lifestyle-related risk factors on cardiac response to ischemia and possibilities to restore impaired ischemic tolerance. Physiol Res 61 (Suppl 2): S1-S10, 2012.

RAVINGEROVÁ T, ČARNICKÁ T, LEDVÉNYIOVÁ V, BARLAKA E, GALATOU E, CHYTILOVÁ A, MANDÍKOVÁ P, NEMČEKOVÁ M, ADAMEOVÁ A, KOLÁŘ F, LAZOU A: Upregulation of genes involved in cardiac metabolism enhances myocardial resistance to ischemia/reperfusion in the rat heart. Physiol Res 62 (Suppl 1): S151-S163, 2013.

SIMKHOVICH BZ, PRZYKLENK K, KLONER RA: Role of protein kinase C in ischemic "conditioning": from first evidence to current perspectives. J Cardiovasc Pharmacol Ther 18: 525-532, 2013.

ŠVORC P, ŠEFARA P, BARČOKOVÁ I: Ischaemic preconditioning - laboratory curiosity or endogenous protection of myocardium before ischaemia? (in Slovak) Kardiológia 12: 21-27, 2003.

TONG H, CHEN W, STEENBERGEN C, MURPHY E: Ischemic preconditioning activates phosphatidylinositol-3kinase upstream of protein kinase C. Circ Res 87: 309-315, 2000.

TSANG A, HAUSENLOY DJ, MOCANU MM, CARR RD, YELLON DM: Preconditioning the diabetic heart: the importance of Akt phosphorylation. Diabetes 54: 2360-2364, 2005.

TYAGI P, TAYAL G: Ischemic preconditioning in myocardium. Acta Pharmacol Sin 23: 865-870, 2002.

VLADIC N, GE ZD, LEUCKER T, BRZEZINSKA AK, DU JH, SHI Y, WARLTIER DC, PRATT PF Jr, KERSTEN JR: Decreased tetrahydrobiopterin and disrupted association of Hsp90 with eNOS by hyperglycemia impair myocardial ischemic preconditioning. Am J Physiol 301: H2130-H2139, 2011.

WALSER R, BURKE JE, GOGVADZE E, BOHNACKER T, ZHANG X, HESS D, KÜENZI P, LEITGES M, HIRSCH E, WILLIAMS RL, LAFFARGUE M, WYMANN MP: PKC $\beta$ phosphorylates PI3K $\gamma$ to activate it and release it from GPCR control. PLoS Biol 11: e1001587, 2013.

WALSH K: Akt signaling and growth of the heart. Circulation 113: 2032-2034, 2006.

WANG Y, TAKASHI E, XU M, AYUB A, ASHRAF M: Downregulation of protein kinase C inhibits activation of mitochondrial $\mathrm{K}_{\mathrm{ATP}}$ channels by diazoxide. Circulation 104: 85-90, 2001.

YANG C, TALUKDER H, VARADHARAJ S, VELAYUTHAM M, ZWEIER JL: Early ischaemic preconditioning requires Akt- and PKA-mediated activation of eNOS via serine1176 phosphorylation. Cardiovasc Res 97: 3343, 2013.

YESHAO W, GU J, PENG X, NAIRN AC, NADLER JL: Elevated glucose activates protein synthesis in cultured cardiac myocytes. Metabolism 54: 1453-1460, 2005.

ZÁLEŠÁK M, BLAŽÍČEK P, PANCZA D, LEDVÉNYIOVÁ V, BARTEKOVÁ M, NEMČEKOVÁ M, ČARNICKÁ S, ZIEGELHÖFFER A, RAVINGEROVÁ T: Severity of lethal ischemia/reperfusion injury in rat hearts subjected to ischemic preconditioning is increased under conditions of simulated hyperglycemia. Physiol Res 63: 577-585, 2014.

ZHENG X, ZU L, BECKER L, CAI ZP: Ischemic preconditioning inhibits mitochondrial permeability transition pore opening through the PTEN/PDE4 signaling pathway. Cardiology 129: 163-173, 2014.

ZU L, ZHENG X, WANG B, PARAJULI N, STEENBERGEN C, BECKER LC, CAI ZP: Ischemic preconditioning attenuates mitochondrial localization of PTEN induced by the ischemia-reperfusion. Am J Physiol Heart Circ Physiol 300: H2177-H2186, 2011. 